\title{
THE RELIGIOUS CASE FOR WATER AS A HUMAN RIGHT FROM THE ANDES
}

\author{
TERENCE A. MCGOLDRICK \\ Theology Department \& Associate Director, Program for Ethics in Business Education, \\ Providence College, Providence, USA
}

\begin{abstract}
For the first time since la conquista, a Latin American country is governed by its indigenous peoples, with a return to traditional models of society that propose an alternative to the failures of globalization. These changes began when the water war erupted in 2000 after the Bolivian government allowed the multi-national, Bechtel, to privatize its water supply with pressure from the World Bank. Ultimately, Bechtel withdrew, giving rise to the grassroots indigenous social movement led by Evo Morales that overturned the Bolivian political order. The country's new constitution grants nature status as a juridical person and states that water can never be privatized. Bolivia was a leading force in the United Nations declaration of water as a human right in 2013. This essay explains the theological cosmovision behind these moral arguments and places them in context.

Keywords: Bolivia, development ethics, indigenous, post-neoliberalism, privatization, rights of nature, water rights
\end{abstract}

\section{INTRODUCTION}

Bolivia is on the front lines of the social disruption due to climate change. The county's glaciers are melting, crops are failing and thousands of people have died due to landslides and floods caused by unprecedented catastrophic storms. It has seen little benefit from World Bank backed neoliberal policies to capitalize its infrastructure development in recent decades, which left the country deeply in debt and with only a few who profited. Water rights became an international cause in 2000, when the Bolivian government sold the public water rights of Cochabamba to Bechtel with World Bank debt forgiveness to sweeten the deal (and 17\% profit margin for Bechtel). Widespread protests erupted when prices for water increased dramatically, doubling in some cases, and all longstanding water cooperatives throughout the region of Cochabamba lost water rights to the multinational by federal decree. Farmers, miners, factory workers, coca growers, students, professionals and church groups joined in strikes, roadblocks and protests [1]. At stake was the question of who should control the country's natural resources. In the end, Bechtel was forced to withdraw at a considerable financial loss and the people regained ownership of the city's water infrastructure and cooperative water systems of the outlying areas [2]. A few years later, the deadlier gas wars over similar neoliberal policies brought down the Lozada government. These events galvanized grassroots social movements and helped bring Evo Morales the leader of the coca farmers, to power as head of the MAS party [3]. The new indigenous government rewrote the constitution in 2009, which proclaimed water a human right and expressly forbids privatizing water [4]. The Bolivian water wars began a chain of events that overturned the Bolivian political order and inspired a worldwide movement to declare water a human right. Bolivia went on to sponsor a UN resolution declaring access to clean water in a human right in 2010 [5].

The problem for developing societies of the Global South is how to balance the human right to water with the practical needs to find ways to finance infrastructure when tax revenues are insufficient. Ironically, there has been a growing consensus in UN conferences since 1992 that privatization is the solution to meet the urgent need to build modern water systems 
for the world's poor [6]. The case of Bolivia is emblematic for the region. I propose to briefly explain the moral basis from the Bolivian church that argue water is the kind of community good that can never be commodified. A sacred attachment to the land and community may have something to contribute in our search for alternatives to a modern rapacious excess of globalized consumer capitalism.

\section{POST-NEOLIBERAL PLURI-NATIONAL BOLIVIA}

Today's post-neoliberal Bolivia is attempting a new model of government inspired by indigenous cultural social organization. For the first time since the colonialism, Bolivia's majority indigenous peoples hold both political power and title to their lands in a more autonomous status as nations. Under its new constitution, indigenous people (Ayllus) were given relative autonomy on matters of food production, community courts, collective ownership of millions of acres of tribal lands and a say on extraction [7]. They were also allowed special representation in congress and bi-lingual education [8]. The new constitution prohibits the privatization of water and renames the country the Plurinational State of Bolivia, reflecting a new form of federalism that allows traditional indigenous usos y custumbres a role in their own governance and a say on the exploitation of their lands. Bolivia's new indigenous government, grants to Mother Nature - Pachamama - the one divine family of all living things, rights as a juridical person. It also established an officer for the defense of the rights of nature. The indigenous Cosmo vision of Pachamama is an inseparable part of the country's political reorganization. For them, as I will explain, water is a sacred gift from the gods, Pachamama and Wirakhocha, thus it does not belong to the state nor can it be sold [9]. Land, water and development are all inter-related issues of growing social tension throughout the global south. The case of Bolivia is an interesting example to understand how an indigenous world view applies Christian ideals to these burning community matters. In 2016, drought has again made water a critical issue in Cochabamba, where water rights remain a vital social justice problem in tension with the forces of development, land ownership and identity.

A good source for the moral evaluation of the just use of water for the region comes from the statements by Bolivia's Catholic Bishops Conference (CEB) [10]. The Bolivian bishops meet regularly, have permanent staffs and advocate on many fronts for their cause, not as an NGO, but as part of the fabric of society [11]. Catholic Social Thought (CST) is a broad area of theology that seeks to apply the ethics of the Christian Gospels to modern social and economic issues [12]. It is the task of the more than 100 Episcopal Conferences of the world to apply CST to their own cultural context and to the particular issues of the local communities. In the case of Bolivia, the CEB has formed national blue ribbon commissions and held hearings throughout the country in a series of public consultations that resulted in three statements over more than a decade on the interrelated vital issues of land, water and development. Their work, together with my own field research where I interviewed leaders of Cochabamba's water wars and church officials, will be my primary source in this article to explain the moral arguments arising from applying an inculturated Christianity to the ethics of clean water access rights.

The dual forces of climate change and growing urbanization throughout the global south are causing rights to clean water to become an acute matter of social justice. The Andean theological perspective, as it is embraced by the Bolivian Church, is an important example of CST in context on one of the most critical social issues of our day. National water policies have been enshrined in the constitutions of numerous countries of the Global south, primarily to protect the poor and voiceless from the undeniable powerful economic interests at play [13]. As Christiana Peppard summarizes, 'clean water flows towards power' [14]. The poor 
are the first victims of our world's growing clean water scarcity. In the Andes, there is an acute awareness that globalization and neoliberalism have benefitted few, which one should keep in mind to understand the region's populism and the anger that spontaneously erupted in the water war and more deadly gas war a couple of years later in Bolivia, over the same neoliberal policies. The people have seen little benefit from the extraction of tremendous mineral wealth over the centuries. Since the mid-sixteenth century, Bolivia has been the source of rich mining veins of silver, gold, and zinc. It has one of the world's largest lithium and antinomy deposits and vast oil and gas fields, yet it is one of the hemisphere's poorest nations, second to Haiti, with half the population living on less than two dollars per day. They see many of these problems due to decisions made in foreign countries with little care for the wellbeing of Bolivia's majority indigenous people or their lands, flora or fauna.

In recent times, clamoring and sometimes violent repercussions of climate change, the longstanding issue of land rights, together with the Bolivian water and gas wars over privatization, spurred the Episcopal Conference of Bolivia to respond with three important CST applications on the subjects of just use and care of the earth (2000) [15], water as a human right (2002) [16] and a third a decade later on the ethics of development (2012) [17]. In the spirit of Andean Pachamama, they advocate for a 'new communion between persons and all the creatures of God's creation as collaborators in God's creative work' [17]. Recognizing that land rights, water and the ethics of development are all inter-related, in this short paper I will focus on the theological ethical perspective on the ethical use and theological value of water from the viewpoint of the Bolivian Church.

\section{AGUA FUENTE DE LA VIDA}

In 2003, the CEB issued a 31-page pastoral letter entitled Water Fountain of Life and Gift for $A l l$. It was the product of dialogue with various sectors of Bolivian society in the aftermath of the water war in 2000. The bishops letter begins by evoking the urgent need, as seen in the suffering of the poor, to reconsider in the light of the Gospel the "use, care and universal destination to everyone without distinction" of the primordial gifts of land and water [16]. The letter begins by giving a detailed explanation of the serious concerns due to the water situation in Bolivia. The free market model and competition have led to overexploitation and contamination of the precious water supply. They cite numerous studies and statistics in describing the social consequences of less than half of Bolivians having access to potable water, which is blamed for about $80 \%$ of the populations' annual illnesses. They also point an accusing finger at the poorly managed extraction industries who consume millions of metric tons of water, leaving it contaminated and causing great ecological damage. They bear witness to a great pain heard in the cry of the poor and the cry of the earth. "A new kind of sin arises due to the abuse of water", they say, "which needs to be redeemed" [16]. They lament that the root of the problem is due to the fact that there is no national plan for sustainable and equitable water access. Hence, this letter is intended to address a "deficit of social conscience and ethical sense or agreement how to resolve the problem" [16].

Water Fountain of Life and Gift for All first acknowledges the sacredness of water as "a living being" in the various indigenous Andean people's beliefs,

Our native people, both east and west, turn to myths to explain their stories. In this wisdom, water plays an important role to understand their origins, their organization, their religion, their rites and their daily lives. The sages teach and believe that water is the source of life, donated freely by God. Manco Capac and Mama Ocllo gushed Lake Titicaca; water, "blood of Mother Earth" is the source that gives and generates life. Picking up the elements of such 
wisdom come to an important conclusion: the water is, for them, as a "living being", with which they can talk and share with other living beings and humans. [16]

The CEB notes the sacred nature of water in both Andean Indigenous and Christian traditions, to argue that water is required for life and thus the realization of every other human right. It is not only an economic good, but also a social and cultural good as well [16]. They note that both Jesus and water give life, cleanse and permeate creation. The Bolivian bishops point out that by choosing the symbol of water and calling himself 'the fountain of life', Jesus expresses a 'profound longing for a dignified human life and underlines the need to care for the gift of water for all' [16]. The wounds of sin both in nature and in human society can only be healed by Christ, who demands as a moral imperative of the last judgment, that his followers give drink to the thirsty (Mt 10:22). This drink given to the thirsty in love, the bishops continue, must be clean water. This is a command of Christ to care for the water as much as for the ones whose life depends upon that water. Water, they add, symbolizes the action of the Holy Spirit, the source of new life that renews the face of the earth. In the next part of their pastoral letter, the CEB goes on to trace the sacredness of water as source of life in Creation, symbolic in the Exodus story where the people share water in solidarity in their journey through the desert. They highlight water's symbol of the new alliance for Ezekiel (47:1-12), where water flows as a blessing from the Temple so that all may flourish. Throughout God's plan as revealed in scripture, the CEB letter notes, "the abundant springs of water is sign of full communion with God, with others, with nature redeemed and with creation transformed" [16]. The statement affirms that this means no one can morally appropriate water or make it a commodity, because God wills that all may benefit from it. Water, in other words, is the example par excellence of the universal destination of creation, because the entire biosphere depends upon it to exist. It is a common good, belonging to every living thing. The Bishops go on to say that all creation subsists in Christ who unites all in love and in harmony with creation. It supports those arguments with texts from the church fathers, John Paul II and the Episcopal Conference of Central and Latin American (CELAM). In this way, it identifies Pachamama with Jesus, which I will explain below.

As sacred and necessary for life, the CEB further develops the moral and theological argument against making water a commodity. It has a sacred value that cannot be morally reduced to the exclusive property of any one or group by privatization. Like the gift of salvation, water is God's gift to all. All creation belongs to God and is, like the gift of life itself, given to all. This universal gift of creation must be cared for in a holistic balance with the common good of all living things. To exclude anyone because they cannot pay for water violates the human right to water and for that matter to life. They affirm that the central point of their message is the need to create 'links of solidarity' to assure that this vital resource be guaranteed for all in all future development strategies [16]. Like every gift, the gift of water includes both rights and responsibilities; it is to be enjoyed by all, and no one can appropriate it. These rights and duties of water are essentially communitarian, to be shared by all in solidarity as one grand family, according to their needs and abilities. At the same time, the CEB statement recognizes the need for capital investment to provide clean water to all and does not categorically forbid private investment where needed [16]. It sets a limit at 3\% profit margin in any future contracts (Bechtel's contract was 17\%). The CEB summarizes lessons learned from the water wars of Cochabamba by calling for transparency, a federal water ministry and broad stakeholder participation in all decisions about water. The best guarantee, they aver, to manage water justly and equitably in harmony with nature is by conscientious, organized and active participation by a broad range of stakeholders [16]. 
The CEB agrees that there should be a shared responsibility in paying for potable water, but argues overall against a neoliberal model which allows only those who can pay to get the water they need and cautions that privatizing water will eventually end up concentrating it in the hands of the wealthy. To do so, they argue and put investors over the state's obligation to the common good and leave little obstacles to over-exploitation and damage to the environment. They acknowledge that paying for clean water is the responsibility that accompanies the right to water, but that costs should be scaled according to the means each has to pay. Paying for water, they concur with the authorities, helps educate the public on the need to care for a fragile and limited water supply that is less likely to be wasted when paid for. They call for an 'ecological conversion' to manage this precious resource and oppose all USA sponsored international resistance to limits on water's commercialization, via free trade agreements, that overrule national rights preventing water commodification [16]. They believe that contamination problems are due to both government enforcement failures and to the fact that the Indigenous have no political process for input as stakeholders in mining and industries use their water or lands. They say that the root of the conflict in Cochabamba's water wars is that no coherent national legislation or policy on foreign investment existed at that time in Bolivia. They lament that there is still little social consciousness or ethical awareness on the continuing impact of development on the country's precious water supply.

Moreover, because it considers these ethical issues surrounding water an international problem, the CEB goes further to call for an international agreement: A 'Universal Declaration of Water as Patrimony of Humanity'. The bishops end their statement stressing that the solution to this grave problem for human life and the planet must "pass through the encounter with the message and person of Jesus Christ" [16]. They conclude affirming that a conversion of heart is ultimately the crux of any true new kind of economic paradigm that will care for, use and share water in justice.

Ten years after its statement on water, the CEB returned to the country's 'ecological crisis' and issued The Universe, God's Gift for all Living Things (2012) [17], a pastoral letter on the environment and development. That letter supports the mandate of the 2010 Mother Earth Laws, seeking a sustainable harmony between the people of the earth and every living thing. It claims that the value of human life would be improved if there was more respect for biological life. The CEB points to the alarming destruction of nature throughout Bolivia that it blames on a culture of death, of men wanting 'to be like God'. The bishops see humanity's moral responsibility since Genesis to be to care for the earth and living things, both gifts to man at creation to be shared and cared for as custodians for future generations. They note that Cochabamba still does not have water for half its population, despite the water wars. It reports that $75 \%$ of greenhouse gasses come from $20 \%$ of the world's population [17]. After elaborating many of the themes and theological arguments of its earlier letter on water, it explains the permanent principles of CST: solidarity, dignity, integral development, the value of work and the common good. The statement then turns to the actual situation of Bolivia. It calls for a fundamental change of heart and abandoning the 'logic of the market and consumerism' model of development. They protest foreign companies patenting Bolivian plants and GMO's widespread use. The Bolivian bishops commit the church to be at the vanguard of environmental care by establishing diocesan commissions, a national education campaign to raise consciousness and the commitment of every pastoral agent of the local church to environmental activism, care and awareness. [17]. It asks parishes to partner with social activist groups and for all to respect nature as God's precious gift to humanity by consuming less energy, paper, etc. They 
also acknowledge the assistance of two German dioceses in their ecological campaign, which proposes planting trees, a yearly creation week, conservation, and partnerships with other NGOs or social groups and recycling among other things. They end the letter calling for an 'alliance for Creation' that reaches out to international and national partners for the good of the earth and an invitation to pray Francis of Assisi's Canticle of Creation.

The CEB's shared vision of justice in light of the sacredness of earth, water and of all nature that we have just summarized in these two pastoral letters arises from indigenous people's worldview, that is compatible with Christian theology, which I will now outline.

\section{AN ANDEAN THEOLOGY OF LAND, WATER AND LIBERATION}

Pachamama for the Andean indigenous peoples is Mother Nature in this profoundly spiritual, localized and holistic life-giving force that has now been given juridical rights to protect it from extractive exploitation and continued harm of its living systems. But it is also a protection of the heritage, identity and community of the indigenous sense of their own meaning of life [18]. The CEB recognizes the indigenous spiritualties that find God in nature. They note in The Universe, God's Gift for all Living Things, that Pachamama is "generous mother that sustains life, expresses the idea care and creation of all the universe, space and time (pacha), where all is related" [17]. The Bishops caution, however, that while the church 'appreciates the truth and goodness' of the Indian Cosmo vision, Christian theology would reject any pantheistic idea of nature. Creation is God's gift to humanity. Moreover, Christianity does not consider nature a person, the CEB denies that one can really grant 'rights to nature', since only persons have rights and too sacred a vision of nature would make using it a taboo. The Andean Cosmo vision has value, they say, because it allows for living harmoniously with the created world, the common good, the cause of the poor and good stewardship of the goods of the earth for our generation and those to come - what they call 'living well' [17]. They point to a parallel to the Pachamama in the theological vision of a Trinitarian God that gives all the creations its existence and telos, which can also be found in Francis of Assisi, Ignatius of Loyola and Duns Scotus [17]. The Second Vatican Council's document Nostra Atate recognizes an authentic experience of the divine in the indigenous peoples' ancient spiritualties. That same Spirit has come into history in the person of Jesus to reveal divine love and purpose for all [19]. In this light, the Bolivian Bishops set Jesus in context of the indigenous sense of nature's sacred Pachamama when they say citing St. Paul:

"We know that the whole of creation groans until the present and labors, longing to be freed from the bondage of corruption into the glorious liberty of the children of God" (Rm 8:22). In order to fulfill this longing we must listen to the Holy Spirit, faithfully following Christ in obedience to God the Father who calls us to be with Him, enjoying the goods of creation transformed. This results in what might be called the "creational" dimension of Christian spirituality: "In him were created all things of heaven and earth ... He is before all and everything subsists in Him ... Christ is all in all things " (Col. $1: 16-17 ; 3: 11)$. In the way of Jesus of Nazareth, who teaches us to see the Father's love in creation, (Lk 12:22-31) we show our respect and harmony with the work of creation, considering it as a means of daily encounter with God and His Son Jesus Christ, with nature and with each other [17].

Wati Longchar explains that for indigenous peoples, there are two axes of liberation theology emerging today. The first is a collective solidarity of resistance, in solidarity of the cross as the only weapon of an oppressed people to challenge the system. It is Trinitarian in the sense that the community is unified in a celebration of life and the self-giving that shares that life, 
'each maintaining identity, but sharing community' and bound together by mutual love. The other axis particular to the indigenous people of God is the spiritual relationship between the land and people and their worldview of creation. She tells us that for indigenous people "political, economic and social justice can be sustained only in relation to the land". The land belongs to all and to the Creator, who dwells within the soil and the people, giving life to the crops and identity to its people. Time and history are 'inseparably interlinked and rooted in the soil'. Land represents a complex spiritual identity with profound theological meaning, which means that liberation without affirming the goodness of the land in a totality of nature is not liberation. It is not only a question of changing social structures, but also healing of the relationship between man and nature liberating the indigenous from being bonded laborers on their own land instead of mutually life-giving [20,21].

A Christianity inculturated by this Pachamama Cosmo vision shares many perspectives of Pope Francis' CST environmental encyclical letter, Laudato Si that develops the Christian ethic of nature in today's world. Both conceive of land, water, all of nature and the human community as sacred and essentially interrelated [22]. Andean liberation theology is one that seeks more than good stewardship, but seeks to find the peace of Christ in a harmony between our society, our model of progress and all of nature [23]. The CEB emphasizes this when it states 'an inherent dimension of the gift of the earth is brotherhood'. The earth cannot be received to be possessed individually, but instead to be shared in solidarity with our brothers [17]. Collective ownership of indigenous lands is one of the reforms of Bolivia's new constitution, which finds moral support from CST. This does not mean that the cardinal principle of private property is being abrogated, but that there is an equally valid basis for the free choice of an indigenous people to own collectively the lands that they identify with as their heritage, spiritually and as life-giving. The universal destination of creation entails a universal responsibility of all to 'guard and care for what has been given to us' [17]. The bishops go on to call for laws that regulate the market so that it may serve humanity and not allow it to determine the distribution of life's necessities, such as water, air, land, food, energy, etc. Using food for energy, and genetically modifying food they call 'a grave error' and blame climate change on industrialized countries. They condemn the idea that the goods of creation belong only to those with technical expertise and financial resources to commercialize them. The statement ends with positions against nuclear power, and call for laws to halt deforestation and exploitation of national reserves. In solidarity, they list numerous practical steps the church is committed to take for the cause of the environment and to emphasize the responsibility and solidarity they consider the best response to convoke an 'alliance for creation', a commitment between God and we human beings to safeguard creation [17].

This theological vision helps explain why an indigenous government would be the first in the world to grant juridical rights to all of nature. Bolivia's 2010 'Law of the rights of mother earth' protects the earth and all living systems, including its indigenous people, as legal persons [24]. It expands a similar 'declaration of the rights of Nature' first passed in Ecuador's constitution of 2008 [25]. In both cases, the law extends the idea of nature, or Pachamama, to broadly encompass all social groups of human communities as well as to all living systems. As the Ecuadoran constitution states in chapter seven, "Nature or Pacha Mama, where life is reproduced and occurs, has the right to integral respect for its existence and for the maintenance and regeneration of its life cycles, structure, functions and evolutionary processes" [25, Chapter 7 art. 71]. It states that "persons have a right to live in a healthy environment that is ecologically balanced, pollution-free and in harmony with the nature" [25, Chapter.6 art. 66]. The Bolivian law grants to mother earth the right to "preserve the functionality of the water cycle, its existence in quantity and quality needed to sustain living systems and its protection 
from pollution for the reproduction of life of Mother Earth and all its components" [24, ch. 3 art. 7]. These laws attempt to remedy the classic problem of the commons, by granting a means for anyone to sue for harm done to mother earth. I asked the Ecuadoran human rights defender, Denise Palacio, when I visited Quito, about the rights of nature. She provided the example of a recent case in Ecuador, where a man was sued for poaching trees under the Ecuadoran version of the law. After 2 years of litigation, he was fined a year's wages, which was about $\$ 5000$. That money does little to cover the cost of litigation or to remedy the damages done to the forest. The case illustrates practical problems with granting juridical rights to nature, however; Mrs. Palacio believes that the law will permit changes to organically emerge over time to resolve those obstacles [26]. The new law in Bolivia also raises questions about its impact on foreign investment upon its vital extraction industries. Will someone sue a multinational for a mining operation's harm to the land and water? Philosophers have been advancing various forms of an environmental ethic that grants the kind of ethical respect and reverence to nature that can only exist between persons since Theodore Roszak and Michael J. Cohen as part of the emerging field of environmental ethics in the late 1970's [27]. However, these South American laws are the first attempt to put a legal framework behind reforms for the problems of the modern environmental destruction [28]. Granting rights to nature is a measure being adopted by numerous nations. In recent years, this movement is gaining momentum. In January 2014, an international tribunal for the rights of nature and mother earth was created by over 150 activists from around the world who met in Cochabamba Bolivia [29]. India has recently given juridical rights as a person to one of its glaciers and New Zealand has done so for the Whanganui river, but no country has done so to date for all of nature as the governments of Ecuador and Bolivia. In Bolivia's case, critics point out that the federal government retains the right enforce these laws as they pertain to the national interests. How the laws will be enforced will ultimately have the most significance in their success to protect nature from the destructive forces of our dominant capitalist system. One should not forget that the local indigenous Bolivian people may have new ownership of their lands and a political voice for the first time since the conquista; however, they do not have veto power over extraction contracts between the federal government and multi-nationals.

\section{CONCLUSIONS}

The Bolivians say they are a poor man sitting on a golden throne. The country's vast mineral and natural resources span an area larger than Texas and California combined, with a population of only 12 million people. The indigenous Pachamama culture offers CST a new expression not only of the sacred interdependence of all life, but also of the meaning of solidarity with nature and with each other. An indigenous 'Pachamama solidarity', born from a deep tribal connection and vision of nature as a sacred whole that the human community itself is contained within, makes it impossible to abstract and instrumentalize water or nature as a commodity. Blood is thicker than water. The consequent rights and responsibilities do not exclude people from managing the common resource by financial instruments, but this is never separated from the one community of sacred nature, life and common good. This is what the indigenous call 'good living' (sumac kawsay), which is a way of doing things in harmony with the community and nature. In this way, solidarity and community are nourished, because all are responsible for all and share the common goods of nature and community that they depend upon. Pachamama solidarity adds a sacred perspective to the communion and interdependence between nature and each other. No individual can exist 
apart from his family, tribe or community, and no human community can exist apart from nature. Especially for the indigenous peoples, it is inconceivable to look at nature and the human community apart from God. The moral imperative of respecting each other that is the basis of every human ethic is essentially tied to nature. All are integral to identity, to harmony, in other words, life flourishes as a symphonic relationship between all these parts, as an integral ecology. It is a stark contrast to the consumerism that identifies modern western individualist culture at the cost of alienation from nature and each other.

The Christian religion proposes an ethic that is compatible with the Andean Cosmo vision and which offers the basis of an ethic for water and development in today's globalized world. Christ the healer brings all humanity into one community and this includes the Pachamama, where, as Water the Fountain of Life puts it,
"Like Jesus of Nazareth, who teaches us to see the love of the father in creation, shows us respect and harmony with the work of creation, considering it as the way to the daily encounter with God and his Son Jesus Christ, with nature and with others." [16]

Bolivia's new Constitution shares the church's vision for social justice fundamentally based on the CST ideal of integral development through fostering participation in economic, political, social and even spiritual life of their society. Many of its positions appeared as part of a national debate years before the new constitution was written. The Catholic Church no longer has a monopoly in Bolivia, yet as part of the fabric of society, it has an important role to play in such a vital national issue. Land sharing in agricultural, mining and timber cooperatives, as well as shared ownership of traditional indigenous lands, is being tested in Bolivia today as a model of subsidiary and solidarity that speaks to the indigenous sacred connection to the land, water and all living things. Bolivia's new constitution hands over more grassroots ownership to indigenous peoples than ever before. Granting rights to mother earth as a person and more grassroots stewardship of native lands, expresses a traditional indigenous Cosmo vision that is compatible with CST's theological vision of nature and human rights. Indeed, it provides a lesson in stewardship of traditional CST with a deeper and more sacred connection between the earth and the human community that could not be as easily warped into domination and wanton destruction.

But the most important question for Bolivia is whether those newly held resources can be managed responsibly by a grassroots population that may be well organized for protests and politics, but lacks the technical education and capital to efficiently export and develop the nation's resource wealth. The capital city of La Paz chose to privatize its municipal water and today $95 \%$ of its residents have water. One of the more critical lessons of the Cochabamba water war was that without stakeholder buy-in on something as critical as water access, one is doomed to fail. Moreover, more nuanced models of privatization have been implemented in other regions, where the water is owned by the people and the infrastructure by the investors, with meaningful stakeholder engagement and remedy frameworks [30]. There are better ways to finance and to justly distribute water without appropriating and commodifying all the water in the system. This is where the responsibility of all to secure the right to water, becomes a basis for policy. Bolivia's bishop's international appeals reflect that its citizens know they cannot achieve development toward the ideals of vivir bien alone, nor can they protect nature without international cooperation. Much of the most valuable land in Bolivia still belongs to the few upper classes, and only the remote less economically valuable lands have been turned into collectives. Pachamama solidarity offers a popular version of development, where all participate, but no nation can modernize without becoming a partner in the global market. Bolivia's MAS government has gained popularity and the economy has been steadily 
growing at 5-6\%, but time will tell if the emerging indigenous organization of economic life and community in harmony with nature will prevail or if they can ultimately contribute to ending Bolivia's ranking as the poorest country of South America. Whether the mother earth laws drive away foreign investment, which Bolivia needs for development, depends upon how these new laws are implemented. The drawn-out controversy over the TIPNIS highway through native lands is an example of such conflicts [31]. It also remains to be seen if placing so much decision power into the hands of the local groups on how the land is used will bring the benefits predicted. A new development model in harmony with nature, in any case, can only be an improvement. The ethical responsibility to water is a human right, which depends on not only grassroots communities, governments and international cooperation, but also investors and transnational corporations. It depends, as the Bolivian bishops say, upon a conversion of heart that respects nature, the community and the common good of water. To see all interdependent, including future generations, makes water a community good that must be used and managed by that community for its flourishing. To the extent that commercial financial instruments serve those ends they are ethical and even necessary. If water is a social good owned by all, as much as a material good and a business opportunity, all share a responsibility in its ethical use. All the water belongs to all, to nature, to persons and to the future generations. When water is wasted or sequestered by the powerful, those who depend upon it, whether animals, plants or persons, suffer. Their right to live with dignity is assaulted when something as necessary for life as water is wasted, or appropriated by another without consideration of their just claims to life. Water, as we all know, is more important than money, for all life and human dignity depend upon it.

\section{ACKNOWLEDGMENTS}

I wish to take this opportunity to thank Providence College for a grant that allowed me to travel to Bolivia and Ecuador for my field research. I would also like to thank Rev. Steven Judd, MM, who organized my interviews with community and church leaders in Bolivia, as well as important actors in the water war of Cochabamba. He was a gracious host and valuable resource. And to Dr. Jeff Pugh of The University of Massachusets, Boston, who helped arrange meetings in Ecuador for this research.

\section{REFERENCES}

[1] Dangl, B., The price of fire: Resource wars and social movements in Bolivia, AK Press: Oakland, CA, 2007.

[2] Farthing, L. C. \& Kohl, B. H., Evo's Bolivia: Continuity and change, Austin, TX: University of Texas Press, 2014.

[3] Shultz, J. \& Draper, M. (Eds.), Dignity and defiance: stories from Bolivia's challenge to globalization, University of California Press: Berkeley, CA, 2009. In an interview on July 4, 2014.

[4] An English translation of the 2009 Bolivian Constitution, available at: https://www. constituteproject.org/constitution/Bolivia_2009?lang=en\#20. (accessed May, 2017).

[5] The United Nations has a group dedicated to water issues called UN Water, available at: www.unwater.org. (accessed May, 2017).

[6] The Camdessus Report of the World Water Council and the 3rd World Water Forum is considered a landmark study on this question, available at: http://www.worldwatercouncil.org/fileadmin/world_water_council/documents_old/Library/Publications_ and_reports/CamdessusReport.pdf. (Accessed April 2017). 
[7] Russell, A. F. S., Incorporating social rights in development: transnational corporations and the right to water. International Journal of Law in Context, 7(1), pp. 1-30, 2011. https://doi.org/10.1017/s1744552310000388

[8] Crabtree, J. \& Chaplin, A., Bolivia: Processes of change, Zed Books: London, UK, 2013.

[9] Olivera, O. \& Lewis, T., Cochabamba!: Water war in Bolivia, South End Press: Boston, MA, 2004.

[10] McGoldrick, T.A., Episcopal conferences worldwide and catholic social thought, in theory and praxis: an update. Theological Studies, 75(2), pp. 376-403, 2014. https://doi.org/10.1177/0040563914529908

[11] McGoldrick, T.A., Episcopal conferences worldwide on catholic social teaching. Theological Studies, 59(1), pp. 22-50, 1998.

https://doi.org/10.1177/004056399805900102

[12] Brady, B.V., Essential catholic social thought. Orbis Books: Maryknoll, NY, 2008, Catholic Social Thought: Encyclicals and Documents from Pope Leo XIII to Pope Francis, 3rd Edition, Eds David J. Obrien and Thomas A. Shannon Orbis Books: Maryknoll, NY 2016.

[13] Meier B.M., Kayser, G.L., Amjad, U.Q. \& Bartram, J., Implementing an evolving human right through water and sanitation policy. Water Policy, 15, pp. 116-133, 2013. https://doi.org/10.2166/wp.2012.198

[14] Peppard, C.Z., Just water, theology, ethics and the global water crisis. Orbis Books: Maryknoll, NY, p. 184, 2014.

[15] Conferencia Episcopal Boliviana, Tierra Madre Fecunda Para Todos, Published by the CEB, La Paz, Bolivia February 2000. Church documents are widely published in multiple formats so they are commonly cited by paragraph, available at: http://www. iglesia.org.bo/media/com_igleobras/documentos/2000.02.14_cpas_cartapastoraltierramadrefecunda.pdf. (accessed January, 2017).

[16] Conferencia Episcopal Boliviana, Agua Fuente de la vida y don para todos, Published by the CEB, La Paz, Bolivia January 2003, available at: http://www.iglesia.org.bo/ media/com_igleobras/documentos/2003.01.12_cpas_cartapastoralaguafuentedevida. pdf. (accessed January, 2017).

[17] Conferencia Episcopal Boliviana El Universo, Don de Dios para la Vida, Published by the CEB, La Paz, Bolivia Feburary 2010. Hereafter (UD-II\#) available at: http://www. iglesia.org.bo/media/com_igleobras/documentos/2012.03.22_cpas_CartaPastoralEluniversodondeDiosparalavida.pdf. (accessed January, 2017).

[18] Arnold, S. P., ¿Cómo hacer teología desde los Andes? Un recorrido dialogado de diferentes campos de la teología en perspectiva de teología andina, Teología Andina, t.2, ed., Josef Estermann, Instituto Superior Ecuménico Andino de Teología (ISEAT), La Paz, Bolivia 2006.

[19] Puebla, 3ra. Conferencia General Del Episcopado Latino Americano (CELAM), p. 234m, 1979, available at: http://issuu.com/celam/docs/puebla/1?e=0. (accessed May 2017). Karl Rahner is one of the most famous theologians to elaborate the meaning of God already there among the indigenous peoples and ahead of the Gospel, yet dependent upon Christ for redemption. See Kelly, Geffrey B., Karl Rahner: Theologian of the Graced Search for Meaning, Fortress press: Minneapolis, MN: 1993. 
[20] Longchar, W., Liberation theology and indigenous people. in The reemergence of liberation theologies. Models for the wenty-First Century, ed. T. Cooper, Palgrave MacMillian: Basingstoke, GBR, pp. 111-121, 2013.

[21] Sheldrake, P., Spaces for the sacred: place, memory and identity, Johns Hopkins University Press: Baltimore, MD, 2001.

[22] Pope Francis, Laudato si, 2015, available at: http://w2.vatican.va/content/francesco/en/ encyclicals/documents/papa-francesco_20150524_enciclica-laudato-si.html. (accessed January 2017).

[23] Martin, K.J., Indigenous symbols and practices in the catholic church: visual culture missionization and appropriation. Ashgate Publishing Group: Aldershot, UK, 2010.

[24] The Rights of Mother Earth (2010) Law 071 of the Plurinational State of Bolivia. Chapter 3 , art.7. These rights are listed as to life, to diversity of life, to water, to clean air, to equilibrium, to restoration and to pollution-free living. Bolivia's Law of the Rights of Mother Earth is published in English translation available at: http://www.worldfuturefund.org/Projects/Indicators/motherearthbolivia.html. (accessed May, 2017).

[25] The English translation of the Constitution of Ecuador, 2008, available at: http://pdba. georgetown.edu/Constitutions/Ecuador/english08.html. (accessed May, 2017).

[26] As part of my interview July 5, 2014, with the help of Professor Jeff Pugh, on a field trip to Bolivia and Ecuador for this research.

[27] Nash, R.F., The rights of nature, edited by Roderick Frazier Nash, University of Wisconsin Press: Madison, WI, 1989.

[28] For a history and legal analysis of the Ecuadoran declaration of rights of nature see: Akchurin, M., Constructing the rights of nature: constitutional reform, mobilization, and environmental protection. Ecuador: Law \& Social Inquiry, 40(4), pp. 937-968, 2015. https://doi.org/10.1111/lsi.12141

[29] Maloney, M., Building an alternative jurisprudence for the earth: the international rights of nature tribunal. Vermont Law Review, 41(1), pp. 129-142, 2016.

[30] Russell, A.F.S., Incorporating social rights in development: transnational corporations and the right to water. International Journal of Law in Context, 7(1), pp. 1-30, 2011. https://doi.org/10.1017/s1744552310000388

[31] Toland, E.M.M., Bolivia: an update on TIPNIS, available at: http://maryknollogc.org/ article/bolivia-update-tipnis. (accessed January 2017). 